MECHANIKA W LOTNICTWIE

ML-XIX 2020

https://doi.org/10.15632/ML2020/261-272

\title{
CHARAKTERYSTYKI AERODYNAMICZNE SKOCZKA SPADOCHRONOWEGO
}

\author{
Maciej Walnik, Katarzyna Strzelecka, Andrzej Gronczewski \\ Politechnika Wrocławska, Wydziat Mechaniczno-Energetyczny, Wroclaw \\ e-mail:maciekwalnik@gmail.com; katarzyna.strzelecka@pwr.edu.pl; andrzej.gronczewski@pwr.edu.pl
}

W artykule przedstawiono: sposób wyznaczenia współczynników siły oporu czołowego dla trzech skoczków o różnej budowie ciała przy wykorzystaniu pionowego tunelu aerodynamicznego; algorytm obliczania prędkości swobodnego opadania z uwzględnianiem zmian gęstości powietrza oraz fizykalnych parametrów skoczka; metodykę wyznaczania maksymalnej prędkości opadania (tzw. prędkość graniczną); zależność zmian prędkości lotu w funkcji czasu opadania dla skoczków o różnych pramateriach fizykalnych; procedurę badań symulacyjnych z wykorzystaniem oprogramowania CFD Ansys Fluent. Wyniki uzyskane podczas obliczeń i badań z wykorzystaniem programu CFD wykazały znaczną zbieżność.

\section{Wstęp}

Spadochroniarstwo to dziedzina sportu uprawiana przez amatorów, jak również przez profesjonalnych zawodników. Występuje kilkanaście dyscyplin sportu spadochronowego, a wśród nich takie jak:

- akrobacje,

- formacje w swobodnym spadaniu,

- freesytle,

- freeflying.

Wszystkie, wymienione powyżej dyscypliny charakteryzują się tym, że oceniane są dokonania zawodników w czasie swobodnego spadania. Jednym z ekstremalnych sportów jest BASE jumping, gdzie zasadniczą częścią skoku jest etap swobodnego spadania. Każdy skok spadochronowy rozpoczyna się krótszą lub dłuższą fazą swobodnego spadania. Znajomość techniki wykonywania skoku podbudowana wiedzą w zakresie aerodynamiki skoczka ma istotne znaczenie dla bezpieczeństwa, jak również sprzyja osiąganiu wysokich wyników w rywalizacji sportowej. Stąd też podjęto próbę wyznaczania charakterystyk aerodynamicznych skoczka spadochronowego w czasie swobodnego spadania.

Opuszczając statek powietrzny na wysokości 4000 metrów nad poziomem morza, skoczek spadochronowy zaczyna poruszać się w specyficzny sposób. Po rozpoczęciu ruchu skoczek gwałtownie przyspiesza, aby po kilkunastu sekundach osiągnąć prędkość maksymalną (graniczną). Następnie stopniowo zwalnia aż do końca trwania ruchu. Na osiąganą przez niego prędkość maksymalną, czas lotu czy zmiany przyspieszenia wypadkowego ma wpływ wiele czynników wynikających z budowy jego ciała, jak również zewnętrznych. Charakterystyka ruchu skoczka zależy $\mathrm{m}$,in. od jego masy, powierzchni i orientacji ciała w przestrzeni, temperatury oraz gęstości powietrza, w którym się porusza.

\section{Eksperymentalne wyznaczenie współczynnika oporu czołowego}

Należy zauważyć, że podczas spadku swobodnego istnieje taka prędkość $v=V_{g r}$, dla której siła oporu zrównuje się co do wartości z ciężarem skoczka. Prędkość ta, to prędkość graniczna 
skoczka, inaczej mówiąc, maksymalna prędkość, z którą może spadać skoczek o danych parametrach w powietrzu o danej gęstości

$$
m g-C_{x} \frac{\rho V_{g r}^{2} S}{2}=0 \quad V_{g r}=\sqrt{\frac{2 m g}{C_{x} \rho S}}
$$

gdzie: $m$ - masa skoczka, $g$ - przyspieszenie ziemskie, $V_{g r}$ - prędkość graniczna, $S$ - powierzchnia odniesienia, $\rho$ - gęstość powietrza, $C_{x}$ - współczynnik aerodynamicznego oporu czołowego.

Współczynnik aerodynamicznego oporu czołowego $C_{x}$ występujący w równaniu prędkości granicznej ciała spadającego swobodnie w atmosferze ziemskiej jest wielkością bezwymiarową, którą określa się eksperymentalnie. W rozpatrywanym przypadku na wartość $C_{x}$ wpływ mają czynniki takie jak proporcje ciała skoczka czy przyjmowana podczas lotu pozycja. Dla pozycji neutralnej współczynnik jest wielkością stałą, charakterystyczną dla danego skoczka.

Celem osiągnięcia pozycji neutralnej skoczek wypycha biodra mocno w dół, tym samym zginając swoje ciało, dzięki czemu środek ciężkości znajduje się możliwie najniżej. Tułów i głowa znajdują się w jednej linii, przy czym głowa odchylona jest do tyłu, co poprawia stabilność pozycji. Nogi rozstawione są pod kątem $45^{\circ}$ do $60^{\circ}$ (na wysokości barków). Podudzia względem uda ustawione są pod kątem $110^{\circ}$ do $120^{\circ}$, tak aby strugi napływającego powietrza napierały na kości piszczelowe i stopy. Ręce skoczka ustawione są symetrycznie względem siebie, przy zachowaniu kątów $90^{\circ}$ między osią tułowia a ramieniem oraz między ramieniem a przedramieniem. Łokcie uniesione są lekko powyżej linii barków.

Celem poznania wartości współczynnika $C_{x}$ dla przeciętnej osoby dorosłej, zbadano wartości prędkości granicznej trzech skoczków w pełnowymiarowym tunelu aerodynamicznym ISG 14.1200 produkcji Indoor Skydiving Germany Group. Pomiarów dokonywano w opisany niżej sposób:

1) pomiar powierzchni odniesienia (powierzchni rzutu ciała skoczka w pozycji neutralnej na płaszczyznę) na podstawie fotografii,

2) pomiar masy ciała skoczków,

3) pojedyncze wchodzenie skoczków do tunelu aerodynamicznego i przyjmowanie przez nich pozycji neutralnej,

4) dobór takiej prędkości przepływu powietrza w tunelu, dla której skoczek nie przemieszcza się w osi pionowej,

5) odczyt prędkości przepływu powietrza (prędkości granicznej skoczka) z aparatury pomiarowej tunelu,

6) pomiar parametrów powietrza - ciśnienia statycznego i temperatury,

7) wyznaczenie gęstości powietrza na podstawie pomiarów z kroku 6 ,

8) wyznaczenie współczynnika oporu aerodynamicznego skoczków zgodnie z równaniem

$$
C_{x}=\frac{2 Q}{\rho V_{g} r^{2} S}=\frac{2 m g}{\rho V_{g} r^{2} S}
$$

gdzie: $Q$ - ciężar skoczka.

Tabela 1. Eksperymentalne wyznaczenie współczynnika oporu skoczków

\begin{tabular}{|c|c|c|c|c|c|}
\hline Skoczek & $S$ & $m$ & $v$ & $\rho$ & $C_{x}$ \\
\hline \hline 1 & $0.666 \mathrm{~m}^{2}$ & $72.9 \mathrm{~kg}$ & $50.0 \mathrm{~m} / \mathrm{s}$ & \multirow{2}{*}{1.206} & 0.712 \\
\cline { 4 - 5 } & $0.562 \mathrm{~m}^{2}$ & $60.0 \mathrm{~kg}$ & $52.5 \mathrm{~m} / \mathrm{s} / \mathrm{m}$ & 0.630 \\
\hline 3 & $0.586 \mathrm{~m}^{2}$ & $61.5 \mathrm{~kg}$ & $49.2 \mathrm{~m} / \mathrm{s}$ & & 0.705 \\
\hline
\end{tabular}

Tunel aerodynamiczny jest korzystnym środowiskiem do wyznaczenia współczynnika $C_{x}$, ponieważ w przeciwieństwie do prawdziwego skoku spadochronowego gęstość powietrza w warunkach laboratoryjnych jest stała oraz możliwa do określenia w łatwy sposób. 


\section{Ruch obiektu spadającego swobodnie w atmosferze ziemskiej z uwzględnieniem zmiany gęstości powietrza wraz z wysokością}

Aby otrzymać możliwie zbliżony do rzeczywistego matematyczny model ruchu skoczka spadochronowego, należy uwzględnić wpływ zmieniającej się wraz z wysokością gęstości powietrza. Siła oporu aerodynamicznego jest wprost proporcjonalna do gęstości powietrza, która z kolei nieliniowo zależna jest od wysokości. Wysokość z kolei w równaniu ruchu zależna jest od czasu. Ze względu na wysoki stopień uwikłania zmiennej gęstości powietrza w równaniu ruchu skoczka analityczne wyznaczenie takiego równania jest trudne i niepraktyczne.

Celem dokładnego opisania ruchu, a zatem przebytej drogi, prędkości i wypadkowego przyspieszenia działającego na skoczka, posłużono się metodą numeryczną dzielącą całość ruchu na odcinki elementarne, po których w przybliżeniu ruch odbywa się ze stałą gęstością. Uproszczenie to można zastosować przy założeniu, że odcinki elementarne będą na tyle małe, że zmiana gęstości powietrza wewnątrz nich jest pomijalnie mała.

Opracowany algorytm przy pomocy arkusza kalkulacyjnego dla zestawu danych wejściowych pozwala z wybraną dokładnością opisać w sposób możliwie zbliżony do rzeczywistego ruch skoczka spadochronowego.

Zestaw danych wejściowych:

- $h_{0}$ - wysokość rozpoczęcia skoku, [m]

- $m$ - masa skoczka, $[\mathrm{kg}]$

- $C_{x}$ - współczynnik oporu czołowego, [-]

- $S$ - pole powierzchni charakterystycznej ciała, $\left[\mathrm{m}^{2}\right]$

- $\Delta t$ - długość trwania elementarnego ruchu, [s]

\section{Algorytm obliczeń}

Tabela 2. Układ komórek algorytmu obliczeniowego

\begin{tabular}{|c|c|c|c|c|c|}
\hline$t$ & $V_{g r}$ & $\rho$ & $h$ & $v$ & $a$ \\
\hline \hline$t_{0}$ & $V_{g r_{0}}$ & $\rho_{0}$ & $h_{0}$ & $v_{0}$ & $a_{0}$ \\
\hline$t_{n}$ & $V_{g r_{n}}$ & $\rho_{n}$ & $h_{n}$ & $v_{n}$ & $a_{n}$ \\
\hline
\end{tabular}

Legenda oznaczeń:

symbol - wartość wyznaczona podczas aktualnego kroku

symbol - wartość wykorzystana do obliczeń podczas tego kroku

symbol - wartość wyznaczona w poprzednich krokach

Tabela 3. Algorytm obliczeń elementarnych odcinków ruchu skoczka

\begin{tabular}{|c|c|c|c|c|c|c|c|}
\hline \multirow[b]{2}{*}{1} & \multirow{2}{*}{$\begin{array}{l}\text { Wprowadzić dane wejściowe } \\
t_{0}=0, \quad h_{0}, a_{0}=g\end{array}$} & $t$ & $V_{g r}$ & $\rho$ & $h$ & $v$ & $a$ \\
\hline & & 0 & & & $h_{0}$ & & $g$ \\
\hline \multirow{3}{*}{2} & \multirow{3}{*}{$\begin{array}{l}\text { Dla zadanej wysokości rozpoczęcia skoku } h_{0} \\
\text { wyznaczyć gęstość powietrza na tej wysokości } \\
\rho_{0}=\rho\left(h_{0}\right)=\rho_{M A W}\left(1-\frac{h_{0}}{44330}\right)^{4.256}\end{array}$} & $t$ & $V_{g r}$ & $\rho$ & $h$ & $v$ & $a$ \\
\hline & & 0 & & $\rho_{0}$ & $h_{0}$ & & $g$ \\
\hline & & & & & & & \\
\hline
\end{tabular}




\begin{tabular}{|c|c|c|c|c|c|c|c|}
\hline \multirow{3}{*}{3} & \multirow{3}{*}{$\begin{array}{l}\text { Wyznaczyć wartość prędkości granicznej skoczka na } \\
\text { aktualnej wysokości } \\
V_{g r_{n}}=V_{g r}\left(\rho_{n}, m, S, C_{x}\right)=\sqrt{\frac{2 m g}{C_{x} \rho_{n} S}}\end{array}$} & \multirow{3}{*}{\begin{tabular}{|l|}
$t$ \\
0 \\
\end{tabular}} & \multirow{3}{*}{ 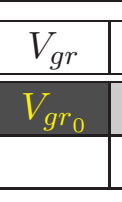 } & \multirow{3}{*}{$\begin{array}{c}\rho \\
\rho_{0} \\
\end{array}$} & \multirow{3}{*}{\begin{tabular}{c|}
$h$ \\
$h_{0}$ \\
\end{tabular}} & & \multirow{3}{*}{ a } \\
\hline & & & & & & & \\
\hline & & & & & & & \\
\hline \multirow{3}{*}{4} & \multirow{3}{*}{$\begin{array}{l}\text { Wyznaczyć wartość prędkości chwilowej skoczka } \\
v_{n}=v\left(t_{n}, V_{g r_{n}}\right)=V_{g r_{n}} \tanh \frac{g t}{V_{g r_{n}}}\end{array}$} & $t$ & $V_{g r}$ & $\rho$ & $h$ & $v$ & $a$ \\
\hline & & 0 & $V_{g r_{0}}$ & $\rho_{0}$ & $h_{0}$ & $v_{0}$ & $g$ \\
\hline & & & & & & & \\
\hline \multirow{3}{*}{5} & \multirow{3}{*}{$\begin{array}{l}\text { Koniec odcinka elementarnego } 0 . \mathrm{W} \text { nowym wierszu } \\
\text { wyznaczyć czas rozpoczęcia kolejnego elementarnego } \\
\text { ruchu } \\
t_{n}=t_{n-1}+\Delta t\end{array}$} & $t$ & $V_{g r}$ & $\rho$ & $h$ & $\bar{v}$ & $a$ \\
\hline & & 0 & $\overline{V_{g r_{0}}}$ & $\rho_{0}$ & $h_{0}$ & $v_{0}$ & $g$ \\
\hline & & $t_{n}$ & & & & & \\
\hline \multirow{3}{*}{6} & \multirow{3}{*}{$\begin{array}{l}\text { Wyznaczyć gęstość powietrza na aktualnej wysokości } \\
\text { (przed odbyciem elementarnego ruchu) } \\
\rho_{n}=\rho\left(h_{n-1}\right)=\rho_{M A W}\left(1-\frac{h_{n-1}}{44330}\right)^{4.256}\end{array}$} & $t$ & $V_{g r}$ & $\rho$ & $h$ & $v$ & $a$ \\
\hline & & 0 & 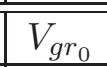 & 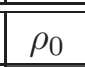 & $\bar{~} \bar{h}_{0}$ & $v_{0}$ & $\overline{g g}$ \\
\hline & & $t_{n}$ & & $\rho_{n}$ & & & \\
\hline \multirow{3}{*}{7} & \multirow{3}{*}{$\begin{array}{l}\text { Wyznaczyć wartość prędkości granicznej skoczka na } \\
\text { aktualnej wysokości (wzór jak w kroku 3) }\end{array}$} & $t$ & $V_{g r}$ & $\rho$ & $h$ & $v$ & $a$ \\
\hline & & 0 & $\overline{V_{g r_{0}}}$ & $\rho_{0}$ & $\bar{~} \overline{h_{0}}$ & $v_{0}$ & $g$ \\
\hline & & $t_{n}$ & $V_{g r_{n}}$ & $\rho_{n}$ & & & \\
\hline \multirow{3}{*}{8} & \multirow{3}{*}{$\begin{array}{l}\text { Wyznaczyć wartość prędkości chwilowej skoczka } \\
\text { (wzór jak w kroku 4) }\end{array}$} & $t$ & $V_{g r}$ & $\rho$ & $h$ & $v$ & $a$ \\
\hline & & 0 & $V_{g r_{0}}$ & $\rho_{0}$ & $h_{0}$ & $v_{0}$ & $g$ \\
\hline & & $t_{n}$ & $V_{g r_{n}}$ & $\rho_{n}$ & & $v_{n}$ & \\
\hline \multirow{3}{*}{9} & \multirow{3}{*}{$\begin{array}{l}\text { Wyznaczyć przyspieszenie wypadkowe działające na } \\
\text { skoczka w danej chwili } \\
a_{n}=a\left(v_{n}, v_{n-1}, t_{n}, t_{n-1}\right)=\frac{v_{n}-v_{n-1}}{t_{n}-t_{n-1}}\end{array}$} & $t$ & $V_{g r}$ & $\rho$ & $h$ & $v$ & $a$ \\
\hline & & 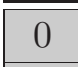 & 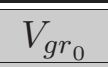 & $\bar{\rho} \rho_{0}$ & $\overline{h_{0}}$ & $\overline{v_{0}}$ & $g$ \\
\hline & & $t_{n}$ & $V_{g r_{n}}$ & $\rho_{n}$ & & $v_{n}$ & $a_{n}$ \\
\hline \multirow{3}{*}{10} & \multirow{3}{*}{$\begin{array}{l}\text { Wyznaczyć wysokość na której przebywa skoczek po } \\
\text { przebyciu elementarnego odcinka } \\
h_{n}=h\left(t_{n}, t_{n-1}, h_{n-1}, v_{n}, a_{n}\right) \\
=h_{n-1}-\left[v_{n}\left(t_{n}-t_{n-1}\right)+\frac{1}{2} a_{n}\left(t_{n}-t_{n-1}\right)^{2}\right]\end{array}$} & $t$ & $V_{g r}$ & $\rho$ & $h$ & $v$ & $a$ \\
\hline & & 0 & $V_{g r_{0}}$ & $\rho_{0}$ & $h_{0}$ & $v_{0}$ & $g$ \\
\hline & & $t_{n}$ & $V_{g r_{n}}$ & $\rho_{n}$ & $h_{n}$ & $v_{n}$ & $a_{n}$ \\
\hline \multirow{4}{*}{11} & \multirow{4}{*}{$\begin{array}{l}\text { Koniec odcinka elementarnego } n \text {. W nowym wierszu } \\
\text { wyznaczyć czas rozpoczęcia kolejnego elementarnego } \\
\text { ruchu (wzór jak w kroku } 5 \text { ) }\end{array}$} & $t$ & $V_{g r}$ & $\rho$ & $h$ & $v$ & $a$ \\
\hline & & \begin{tabular}{|l|}
0 \\
\end{tabular} & $\begin{array}{l}V_{g r_{0}} \\
\end{array}$ & \begin{tabular}{l|l|}
$\rho_{0}$ \\
\end{tabular} & $h_{0}$ & $v_{0}$ & $g$ \\
\hline & & $t_{n-1}$ & $V_{g r_{n-1}}$ & $\rho_{n-1}$ & $h_{n-1}$ & $v_{n-1}$ & $a_{n-1}$ \\
\hline & & $t_{n}$ & & & & & \\
\hline 12 & \multicolumn{7}{|l|}{$\begin{array}{l}\text { Jeśli } h_{n}>0 \text {, powtórzyć kroki } 6-12 \text {. } \\
\text { W przeciwnym wypadku: koniec algorytmu }\end{array}$} \\
\hline
\end{tabular}

Wygenerowany w ten sposób zestaw danych pozwala na wyznaczenie dokładnych charakterystyk zmian wszystkich obliczanych wielkości oraz na określenie wartości dodatkowych parametrów opisujących ten ruch, takich jak:

- $V_{\text {max }}$ - prędkość maksymalna skoczka, punkt przegięcia funkcji prędkości od czasu, 
- $t_{\text {skoku }}$ - czas potrzebny na pokonanie drogi od $h_{0}$ do $h_{n} \approx 0$,

- $t_{g r}$ - czas osiągnięcia prędkości granicznej.

\section{Wpływ parametrów fizykalnych skoczka na charakterystyki ruchu}

\subsection{Masa skoczka}

Wykonano szereg symulacji dla różnych mas skoczka przy założeniu, że powierzchnia jego ciała (powierzchnia odniesienia) oraz współczynnik oporu aerodynamicznego są stałe i wynoszą: $C_{x}=0,67$ (przyjęto na podstawie pomiarów eksperymentalnych, odpowiada dorosłemu człowiekowi o przeciętnej budowie ciała), $S=0,7 \mathrm{~m}^{2}$.

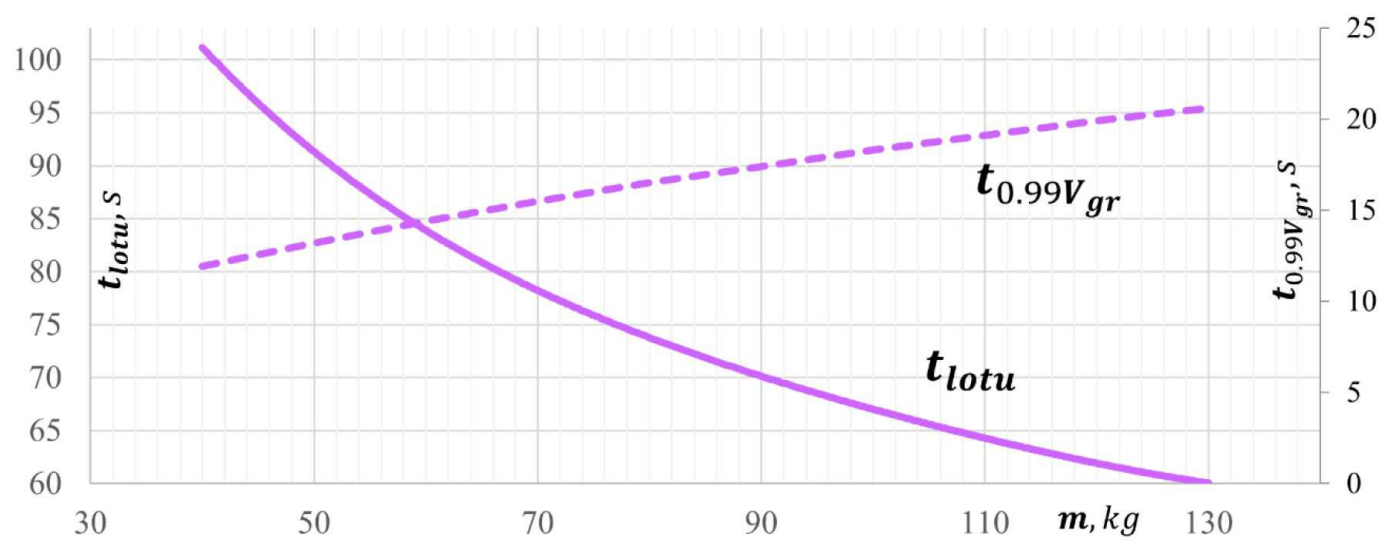

Rys. 1. Zależności czasu trwania lotu oraz czasu osiągnięcia 99\% prędkości granicznej od masy skoczka

Linia ciągła na przedstawionym wyżej wykresie opisuje zależność czasu trwania lotu (od wyskoczenia na $h_{0}=4000 \mathrm{~m}$ do $h=0 \mathrm{~m}$ ) od masy skoczka. Linia przerywana pokazuje czas potrzebny skoczkowi o danej masie na osiągnięcie $99 \%$ wartości prędkości granicznej.

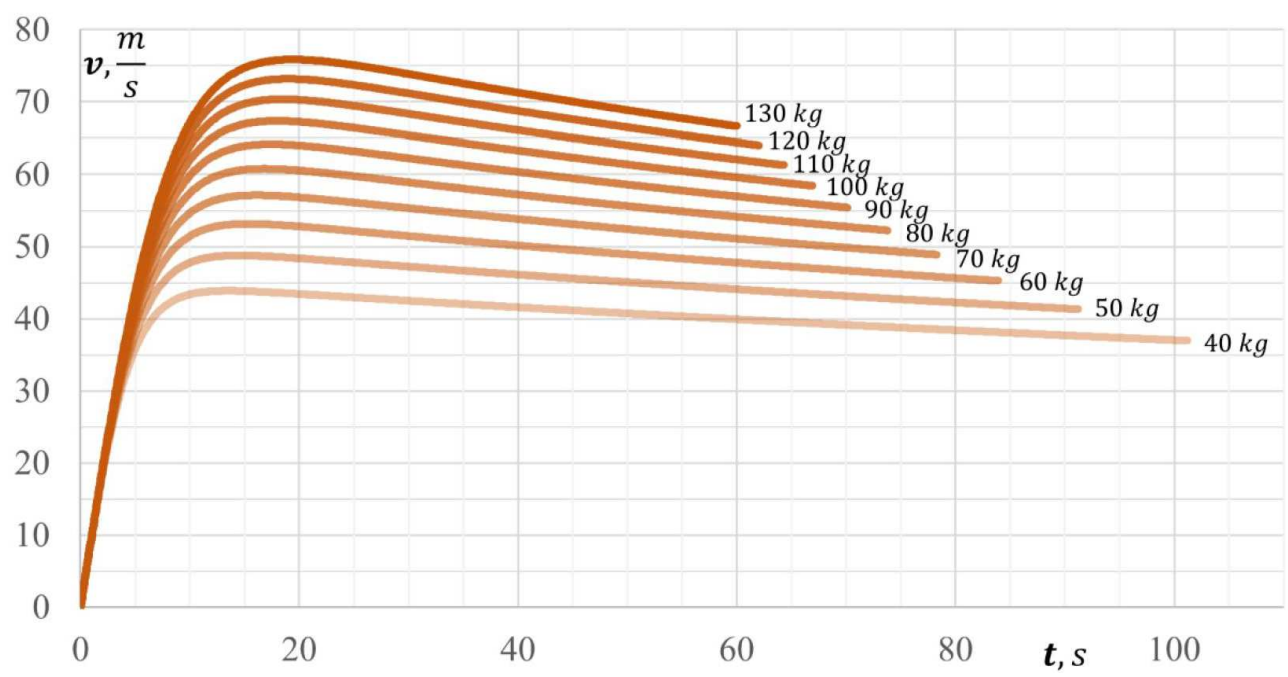

Rys. 2. Zależność prędkości spadania od czasu dla różnych mas skoczka

Im mniejsza masa skoczka, tym bardziej wypłaszczona i mniej stroma jest krzywa opisująca zmianę prędkości lotu w czasie. Należy zauważyć, że do pewnego momentu ( $80 \%$ prędkości maksymalnej) prostoliniowe części krzywych dla wszystkich mas niemalże pokrywają się. Dzieje się tak, ponieważ siła oporu dla tego zakresu prędkości jest na tyle mała, że ruch przypomina ruch jednostajnie przyspieszony, w którym masa spadającego obiektu nie ma wpływu na prędkość jego spadania. 


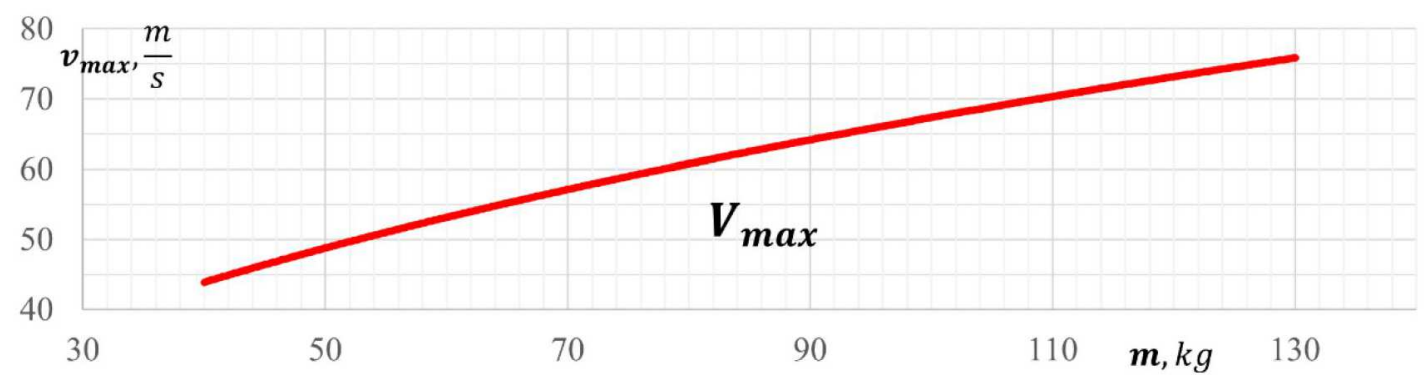

Rys. 3. Zależność prędkości maksymalnej osiąganej przez skoczka od jego masy

Zależność prędkości maksymalnej skoczka od jego masy, przedstawioną na wykresie na rys. 3, ma kształt wycinka odwróconej paraboli. Zależność ta jest związana z równaniem na prędkość graniczną $\sqrt{2 m g /\left(C_{x} \rho S\right)}=V_{g r}$, skąd widać, że wartość prędkości granicznej zależy od pierwiastka masy skoczka.

\subsection{Współczynnik oporu aerodynamicznego, powierzchnia ciała skoczka}

Obie wielkości $\left(C_{x}\right.$ oraz $\left.S\right)$ występują w równaniu ruchu skoczka obok siebie jako czynniki mnożenia, a ich rozdzielenie i zmienianie pojedynczo nie ma fizycznego sensu $\left(C_{x}\right.$ wyznaczany jest dla konkretnej $S$ ). Celem zobrazowania zmian w charakterystykach ruchu spowodowanych zmianą współczynnika oporu bądź powierzchni ciała skoczka wykonano szereg symulacji dla różnych wartości iloczynu $C_{x} S$, przy założeniu, że masa skoczka jest stała i wynosi $m=75 \mathrm{~kg}$.

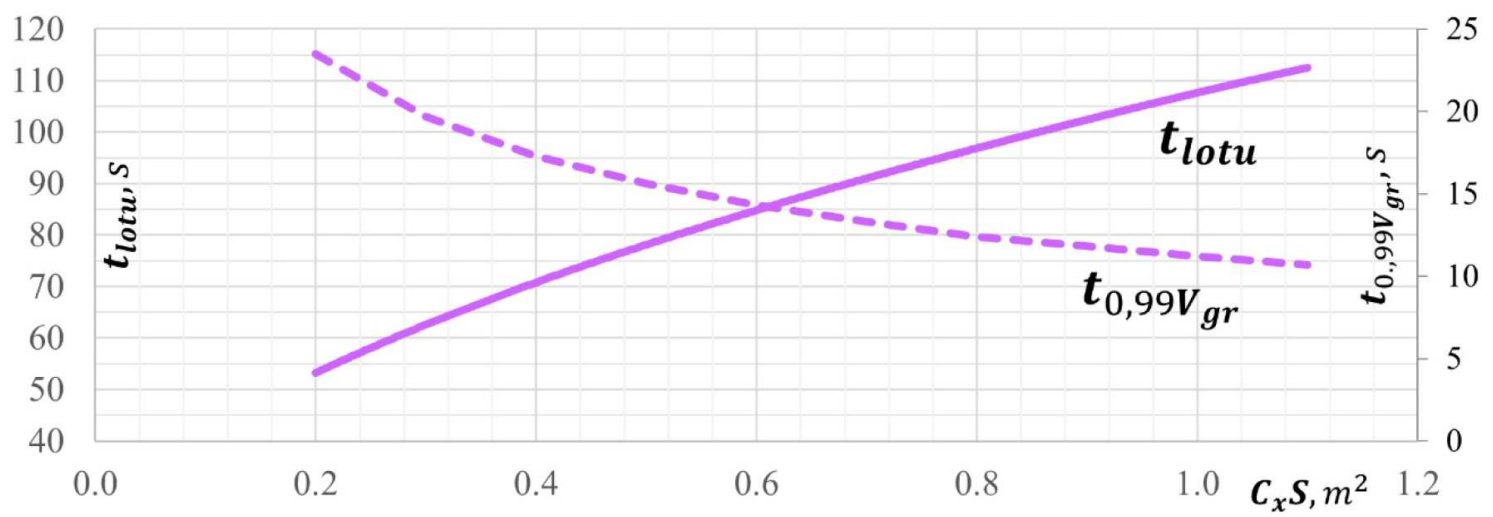

Rys. 4. Zależność czasu trwania lotu oraz czasu osiągnięcia 99\% prędkości granicznej od iloczynu współczynnika oporu i powierzchni ciała skoczka

Zależność pokazana na rys. 6 ma kształt paraboli z ramionami skierowanymi ku górze (odwrotnie niż w zależności od masy). Podobnie jak dla masy, równanie krzywej $V_{\max }$ jest związane z przebiegiem funkcji prędkości granicznej $\sqrt{2 m g /\left(C_{x} S \rho\right)}=V_{g r}$, skąd widać, że wartość prędkości granicznej zależy od pierwiastka odwrotności iloczynu $C_{x} S$.

\section{Symulacja ruchu skoczka w oprogramowaniu CFD}

Korzystając z udostępnionego w domenie publicznej modelu sylwetki człowieka, ustawiono takie wartości kątów zgięcia stawów, aby sylwetka ciała odpowiadała pozycji neutralnej, przyjmowanej przez skoczków spadochronowych oraz siły na płaszczyźnie poziomej (prostopadłej do kierunku spadania) były jak najmniejsze - rozpatrujemy spadek pionowy bez prędkości horyzontalnej. 


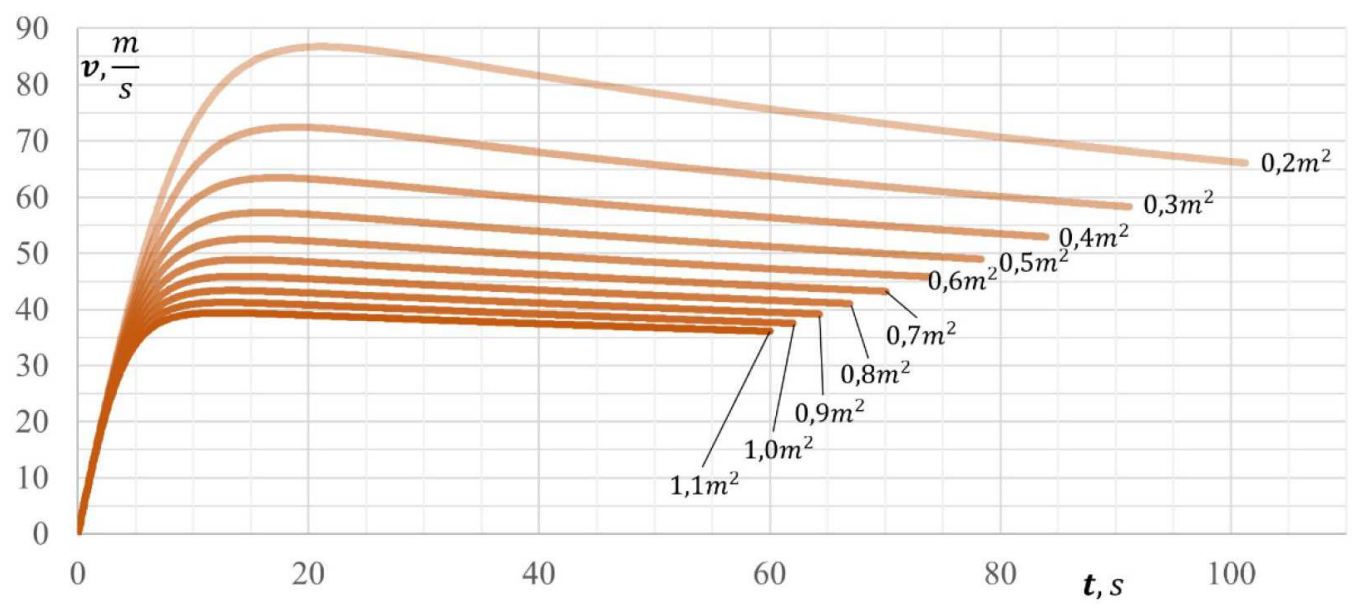

Rys. 5. Zależność prędkości spadania od czasu dla różnych wartości iloczynu współczynnika oporu i powierzchni ciała skoczka

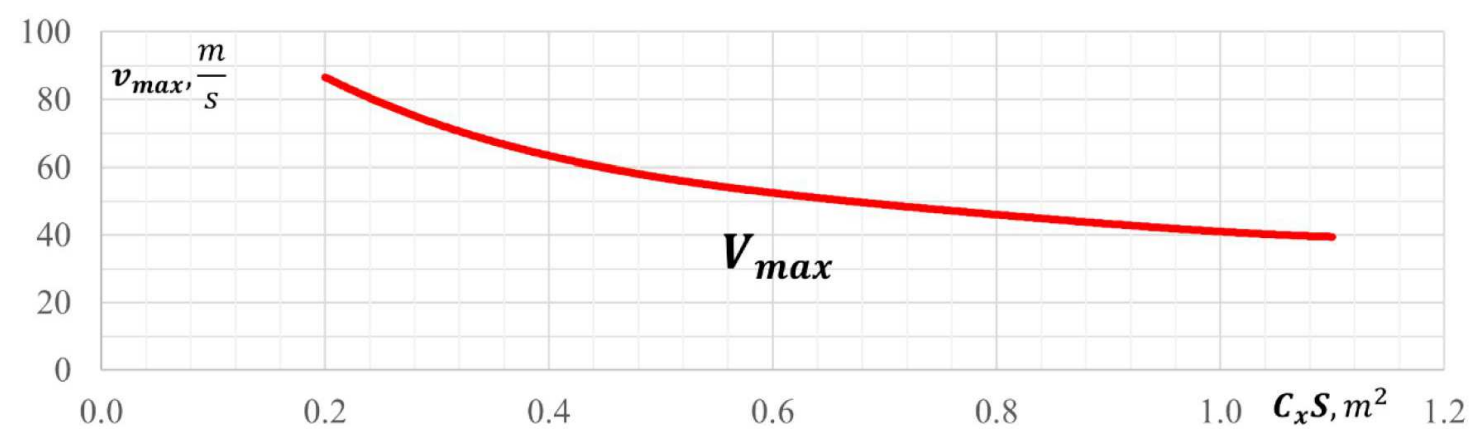

Rys. 6. Zależność prędkości maksymalnej osiąganej przez skoczka od wartości iloczynu współczynnika oporu i powierzchni ciała skoczka

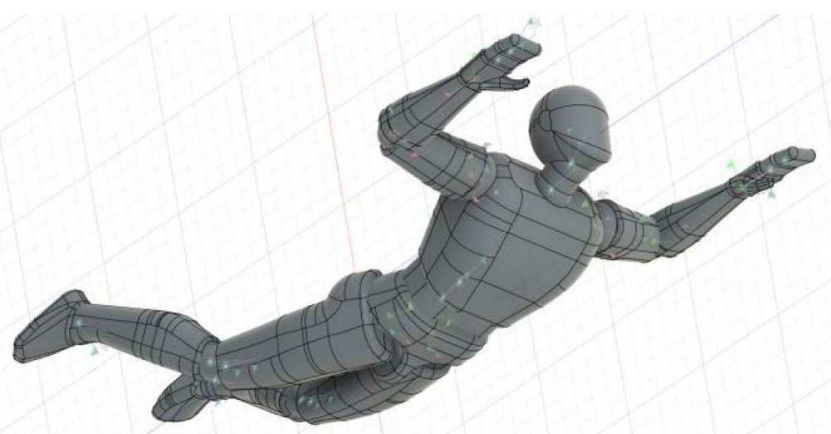

Rys. 7. Model skoczka w pozycji neutralnej z widocznymi wiązaniami stawów

\subsection{Konfiguracja projektu w ANSYS Workbench}

Przygotowany w odpowiedniej pozycji model skoczka zaimportowano do modułu DesignModeler programu ANSYS Workbench, a następnie utworzono wokół niego kanał, którym przepływać będzie płyn podczas symulacji. Kanał ten składa się z półkolistej części wlotowej (przed skoczkiem) oraz cylindrycznej części przepływowej wokół i za modelem. Średnica kanału (8 m) stanowi kilkakrotność najdłuższego wymiaru badanego modelu, dzięki czemu opływ przy granicy kanału nie wpłynie negatywnie na wyniki symulacji w obszarze modelu i w jego bezpośrednim sąsiedztwie. 
W stworzonym w poprzednim kroku obszarze przepływu płynu wygenerowano siatkę obliczeniową. Przyjęto maksymalny rozmiar elementu siatki równy $1.3 \mathrm{~m}$ dla maksymalnego rozmiaru pojedynczego poligonu $0.8 \mathrm{~m}$, Obszar bezpośredniego sąsiedztwa modelu wypełniono gęstszą siatką z zadanym rozmiarem elementu równym $0.02 \mathrm{~m}$, a powierzchnię modelu, stanowiącą granicę między płynem a ciałem stałym, pokryto sztywną siatką o rozmiarze elementu $0.01 \mathrm{~m}$.

W ustawieniach symulacji Fluent wybrano model lepkości k-epsilon wykonalny (ang. realizable $k$-epsilon viscous model), jeden z najczęściej wykorzystywanych modeli obliczeniowych w numerycznej mechanice płynów. Skorzystano z opcji „non-equilibrium wall functions” dla obliczeń w sąsiedztwie granicy płynu. Wektor prędkości płynu w symulacji jest równoległy do osi $X$, zgodnie z przyjętym wcześniej układem odniesienia względem modelu skoczka.

\subsection{Wyniki symulacji CFD}

Przeprowadzono 55 symulacji (po 50 iteracji każda) opływu ciała skoczka dla parametrów wynikających z zastosowanego algorytmu obliczeniowego. Oprócz wartości siły oporu czołowego działającej na model skoczka, symulacja szczegółowo obrazuje zachowanie powietrza opływającego ciało.

Tabela 4. Porównanie wyników metody analitycznej i CFD

\begin{tabular}{|l|c|c|}
\cline { 2 - 3 } \multicolumn{1}{c|}{} & Metoda analityczna & Metoda CFD \\
\hline \hline Czas skoku $\left(h_{0} \rightarrow h_{n}=0\right)$ & $66,5 \mathrm{~s}$ & $65,5 \mathrm{~s}$ \\
\hline Prędkość maksymalna $V_{\max }$ & $67,81 \mathrm{~m} / \mathrm{s}$ & $68,93 \mathrm{~m} / \mathrm{s}$ \\
\hline Czas osiągnięcia $V_{\max }$ & $18,0 \mathrm{~s}$ & $16,5 \mathrm{~s}$ \\
\hline
\end{tabular}

Różnica między metodą analityczną a CFD jest bardzo niewielka. Oba sposoby obliczeń przyniosły jednakowe efekty.

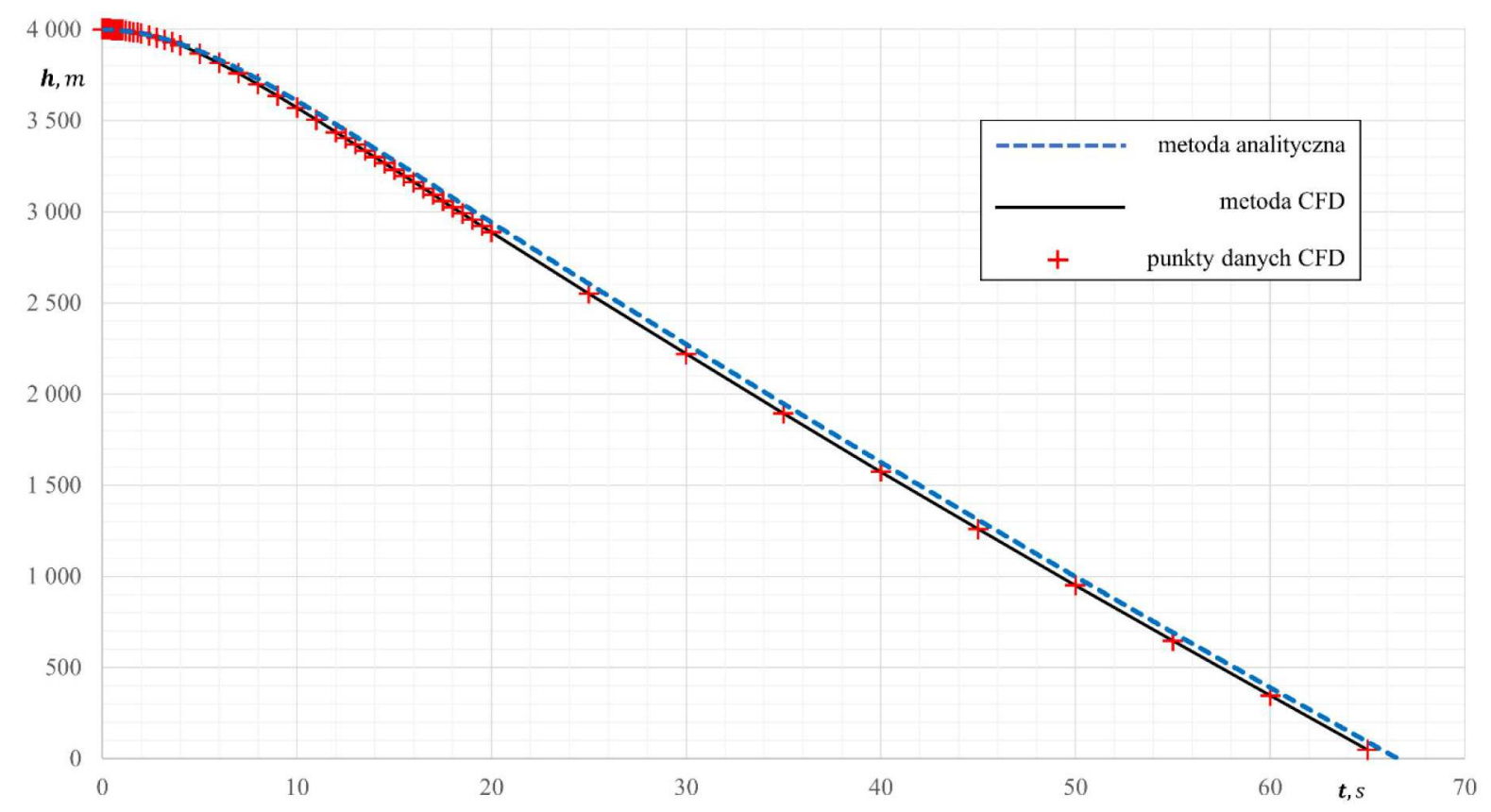

Rys. 8. Zależność wysokości od czasu - metoda analityczna i CFD

Na rysunkach 11-14 przedstawiono wizualizacje ciśnienia powietrza przy powierzchni ciała skoczka oraz w płaszczyźnie równoległej do opływu, poprowadzonej w kierunku od głowy do krocza. 


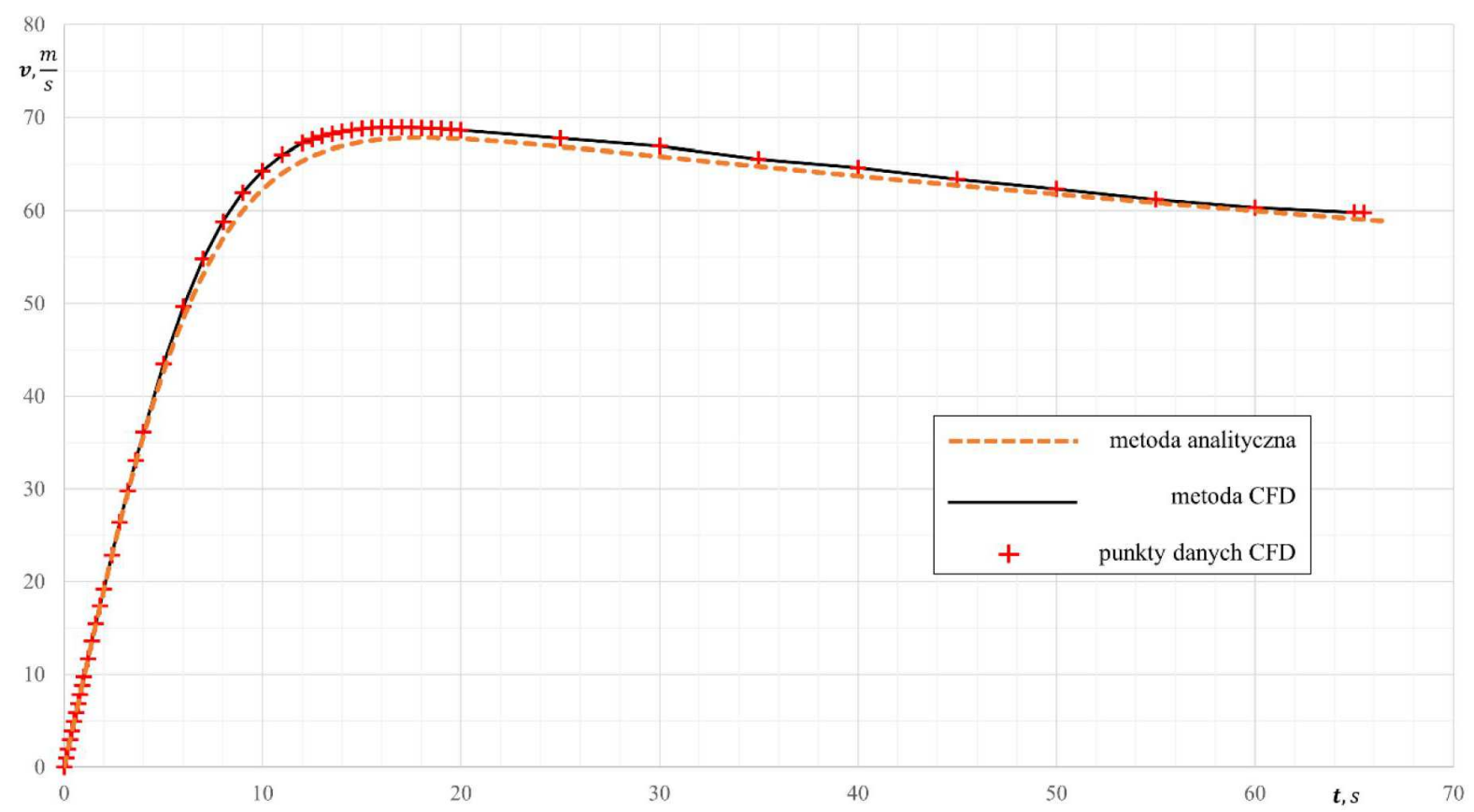

Rys. 9. Zależność prędkości od czasu - metoda analityczna i CFD

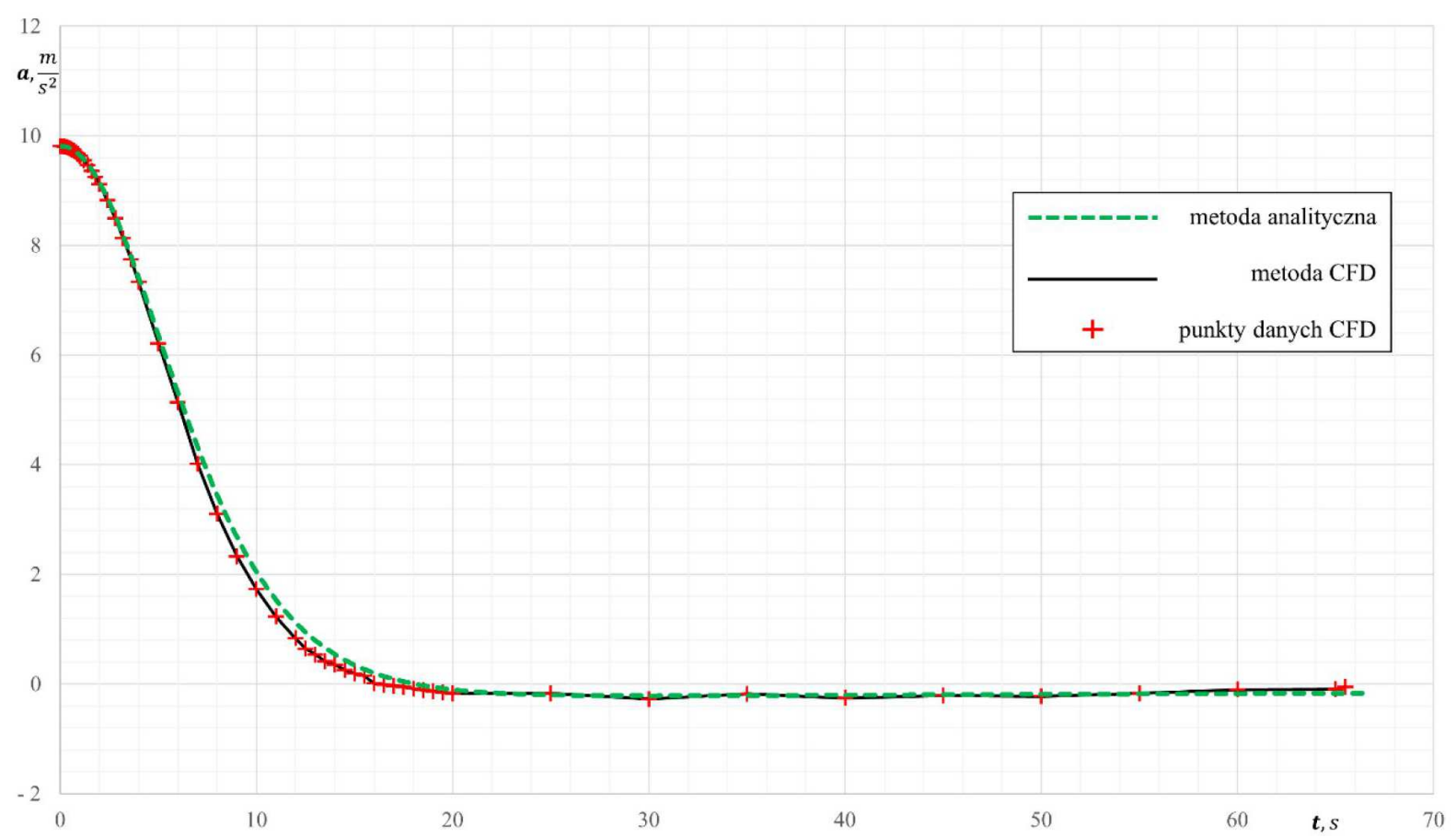

Rys. 10. Zależność przyspieszenia wypadkowego od czasu, metoda analityczna i CFD 


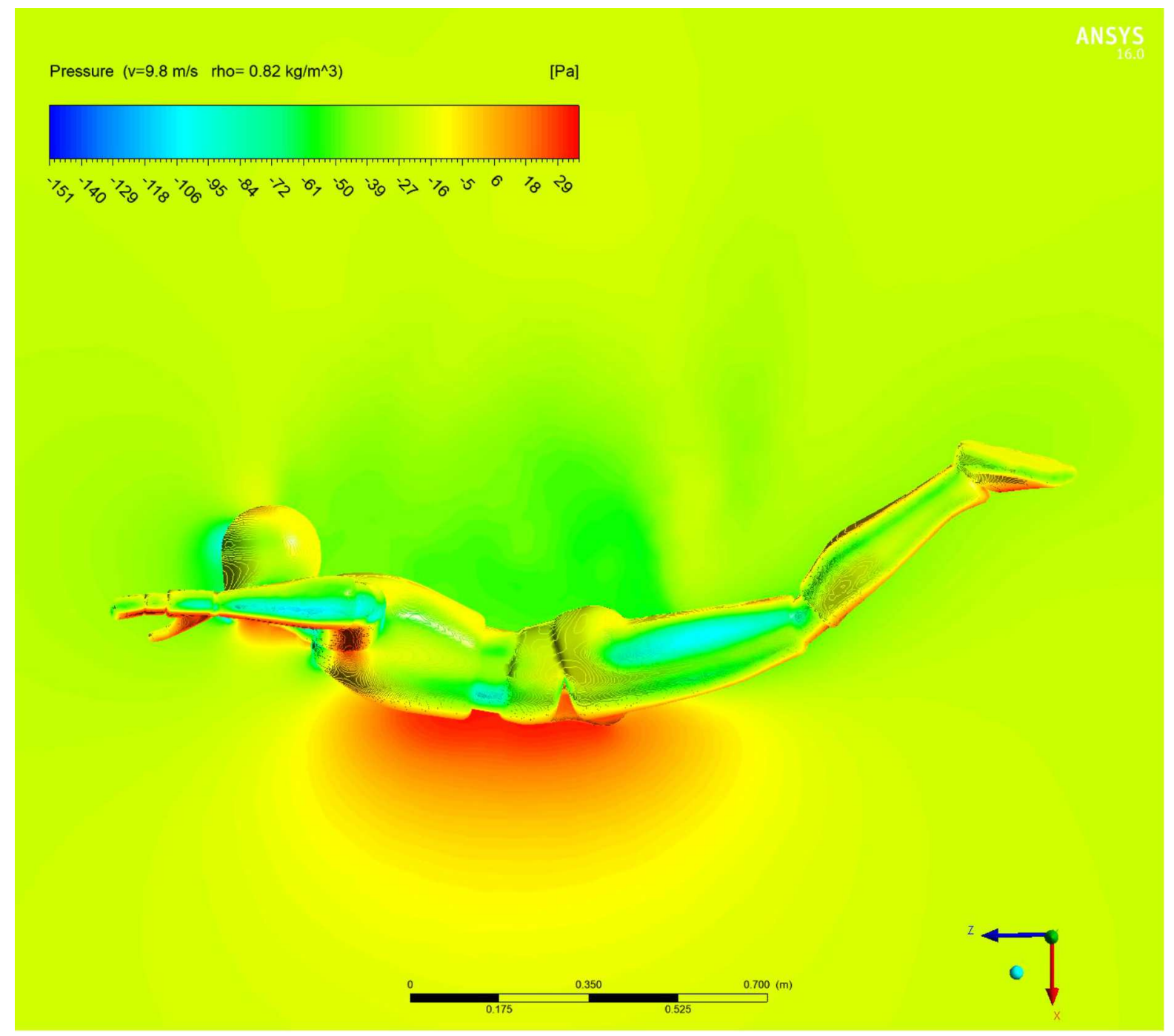

Rys. 11. Ciśnienie względne $(t=1.0 \mathrm{~s})$, widok z boku

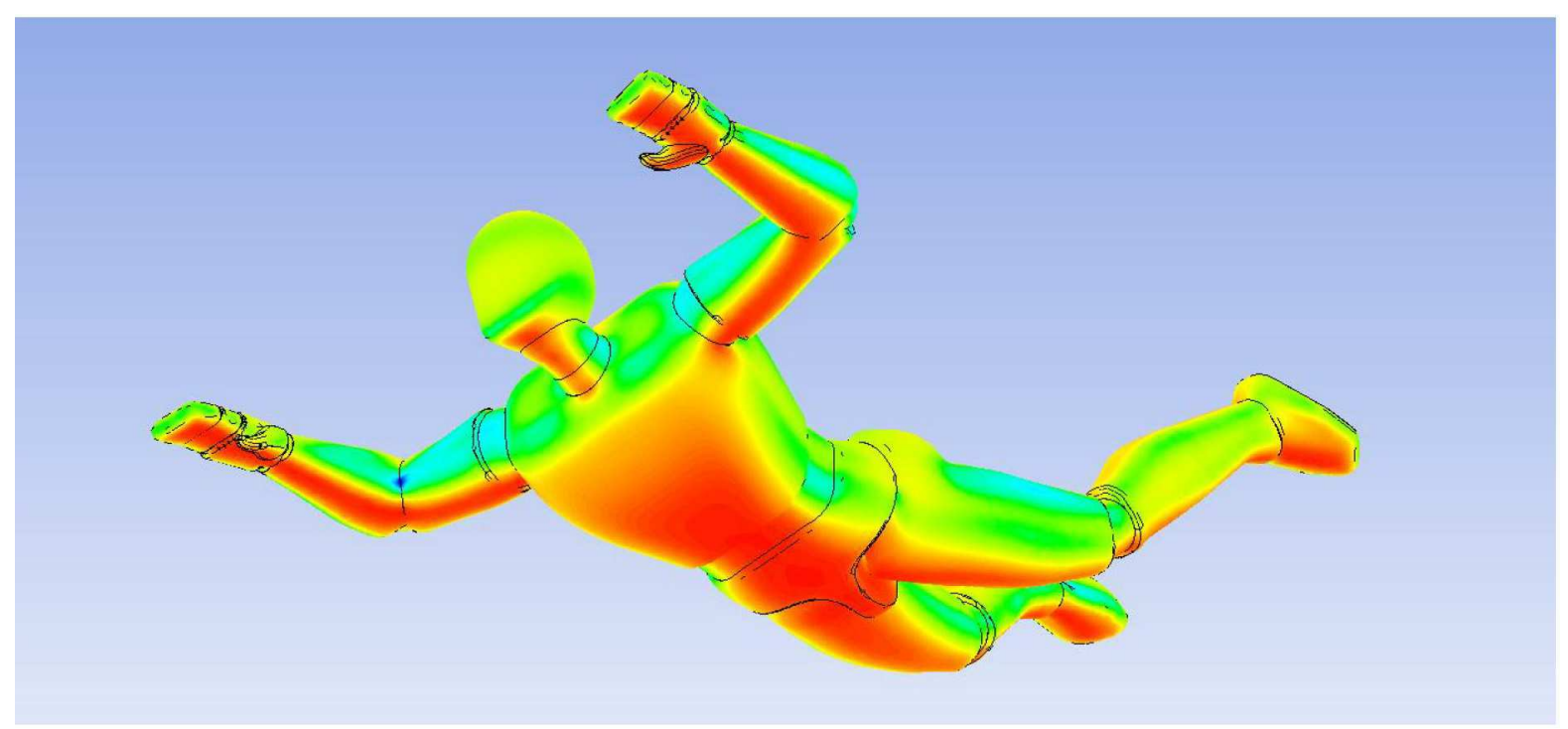

Rys. 12. Ciśnienie względne $(t=1.0 \mathrm{~s})$, widok izometryczny 


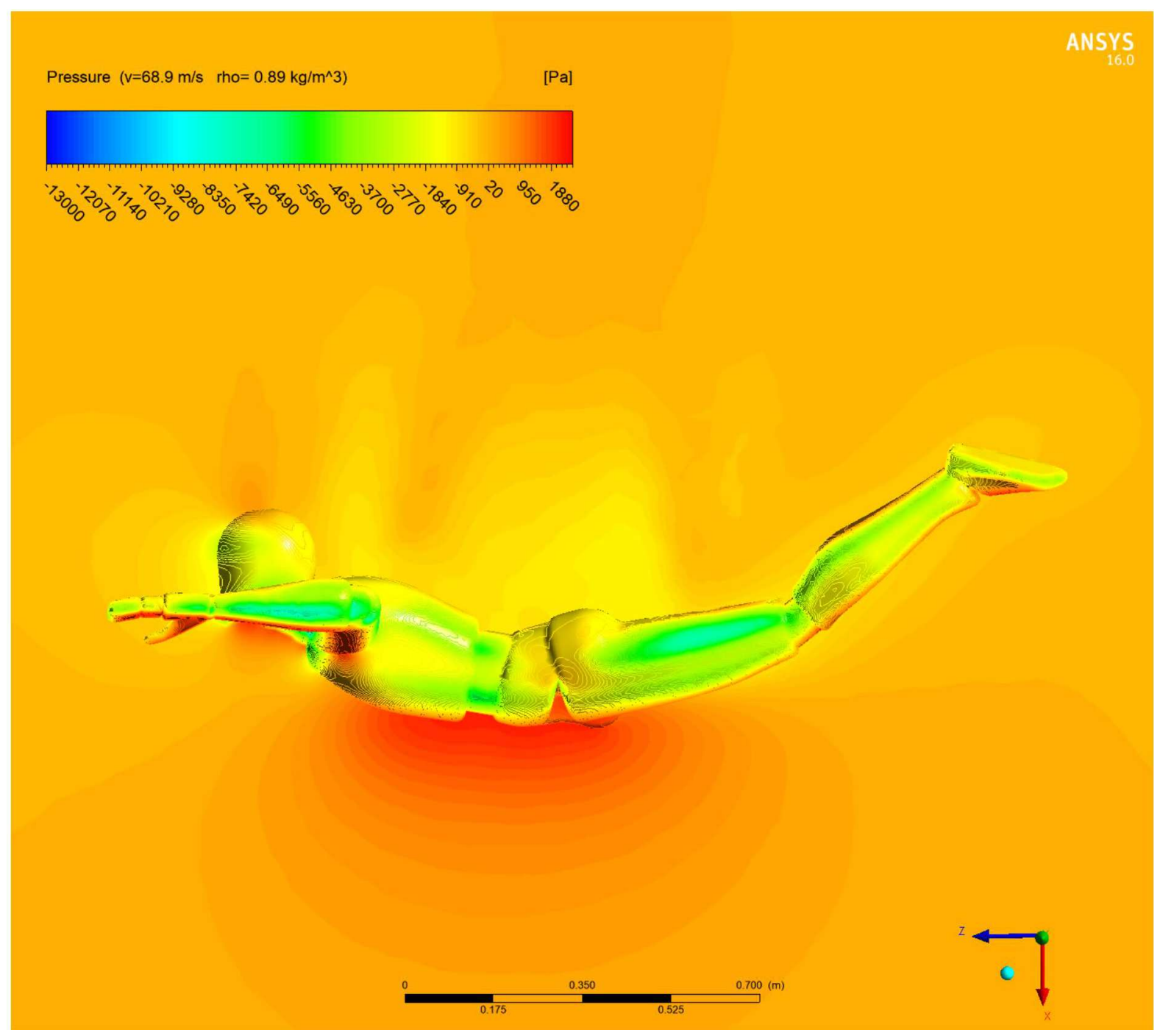

Rys. 13. Ciśnienie względne $(t=16,5 \mathrm{~s})$, maksymalna prędkość spadania, widok z boku

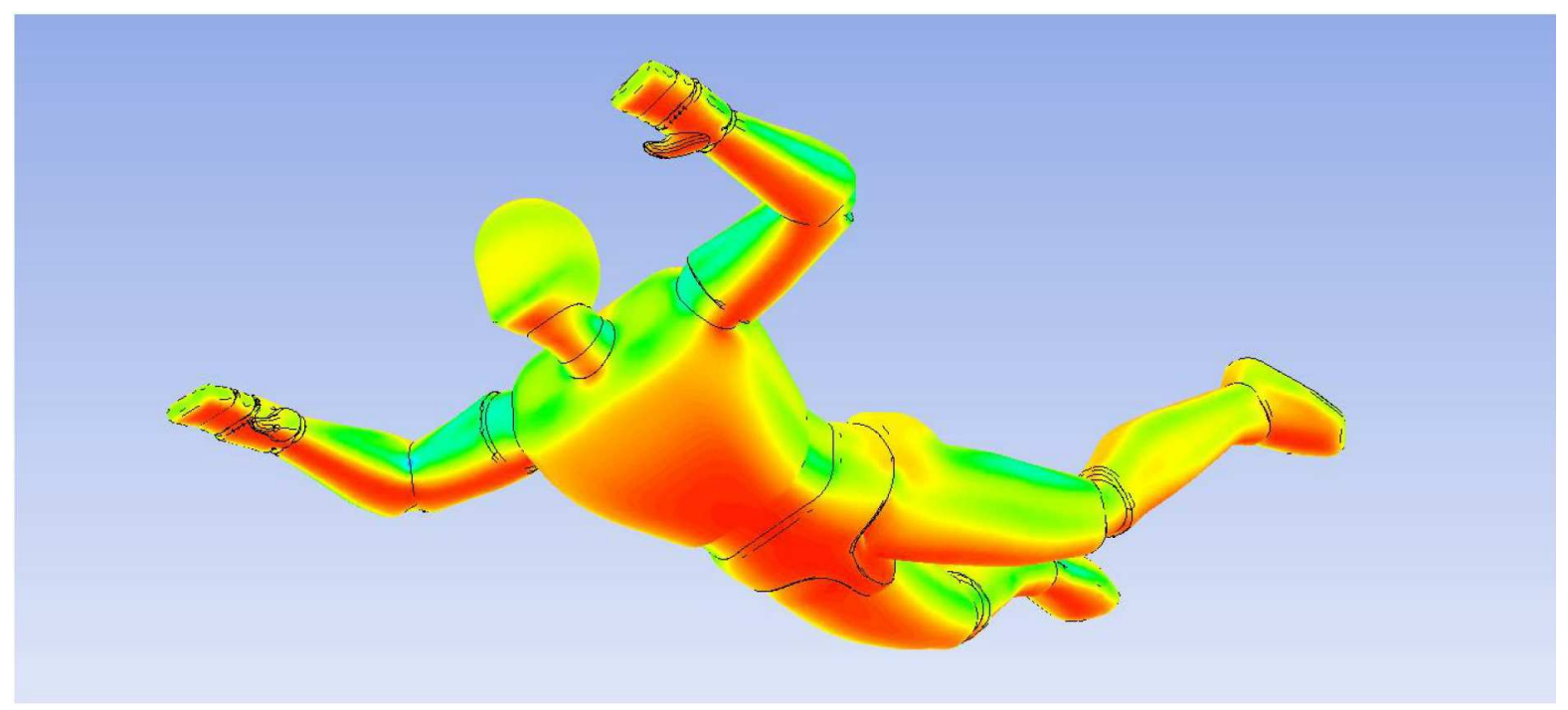

Rys. 14. Ciśnienie względne $(t=16,5 \mathrm{~s})$, maksymalna prędkość spadania, widok izometryczny 
Uwaga. Wizualizacje na rys. 11 i 12 oraz 13 i 14 wykonano w innej skali ciśnień dla zachowania czytelności.

\section{Podsumowanie}

Dla każdego ciała poruszającego się względem otaczającego je płynu, wyznaczyć można wielkość charakterystyczną: współczynnik oporu czołowego. Znając go, można w prosty sposób, stosując pewne uproszczenia, opisać zachowanie skoczka w przestrzeni. Współczynnik wyznaczyć można eksperymentalnie, wykorzystując tunel aerodynamiczny, jak również obliczeniowo, przy pomocy oprogramowania CFD. W ramach pracy zastosowano obie wspomniane metody, porównując charakterystyki ruchu skoczka o znanym (założonym współczynniku) oraz te obliczone komputerowo.

Dzięki oprogramowaniu CFD, zakładając możliwość stworzenia trójwymiarowego modelu badanego człowieka, możliwe jest dokładne i nieobarczone znaczącym błędem wyznaczenie charakterystycznego dla niego współczynnika $C_{x}$. Znając wartość współczynnika, korzystając z zaprezentowanej w pracy metody, można w prosty sposób otrzymać wykresy wysokości, prędkości i przyspieszenia wypadkowego w funkcji czasu.

Projekt ten można potencjalnie rozwinąć w kierunku optymalizacji charakterystyk ruchu skoczka, poprzez zbadanie, w jaki sposób w zależności od ubranego kombinezonu zmienia się współczynnik oporu czołowego. Ponadto rozważania można rozszerzyć o siły wypadkowe działające w płaszczyźnie prostopadłej do kierunku ruchu skoczka, co pozwoliłoby na wyznaczenie i opisanie całego toru lotu w przestrzeni trójwymiarowej.

\section{Bibliografia}

1. Skydive OlsZTYN - Skrypt skoczka spadochronowego http://skydive.olsztyn.pl/pdf/Zasady\%20skoku\%20spadochronowego.pdf [dostęp 10.06.2020]

2. Yitang Design Studio - Model ciała człowieka [dostęp 10.06.2020] http://1t.qunheb.com/ [dostęp 06.01.2020]

3. Computational Fluid Dynamics Online - Model obliczeniowy k-epsilon https://www.cfd-online.com/Wiki/K-epsilon_models [dostęp 06.01.2020]

\section{Aerodynamic characteristics of a parachute jumper}

The main goal of this paper is to calculate the factor of the force of aerodynamic resistance and to describe characteristics of the speed of falling for various altitudes, considering physical features of a man as well as flight altitude. In the article, the aerodynamic resistance of three jumpers of different body builds is calculated. The algorithm for calculating the speed of free falling with consideration of changes in air density and physical parameters of the jumper; the method of calculating the maximum speed of the free-fall (i.e. terminal velocity); the dependence of changes in the flight speed in falling time for jumpers of different physical parameters; the procedure of experimental simulation with the use of CFD Ansys Fluent software as well as the results of the said simulations; comparison of simulation results to those obtained by an analytical approach are addressed in the paper. The results obtained from simulations and calculations have proved to be largely similar. 